\title{
MAKNA BUDAYA PADA BIKAGO YANG MENGANDUNG PREFIKS O- DAN GO- DALAM BAHASA JEPANG (KAJIAN LINGUISTIK ANTROPOLOGI)
}

\author{
Dhiya Fithriyana*, Idah Hamidah, Hartati \\ Program Studi Sastra Jepang, Universitas Jenderal Soedirman, Purwokerto, Indonesia
}

\begin{abstract}
This study examines the cultural significance of bikago that contains the prefix $o$ - and goin Japanese (anthropological linguistic studies). The purpose of this study is to describe the cultural significance that lies behind the use of the prefix $o$ - and go- on bikago in Japanese (Anthropological Linguistic Study).Theories used in this research are culture, anthropological linguistics, morphology, cultural meaning, whorf sapor hypothesis, nouns and o- and go- prefix theories. The type of method used is a qualitative description with a method of collecting data collected from various books, namely the book Minna no Nihonggo Shokyuu I \& II, Minna no Nihonggo Yasashi Sakubun and Basic Kanji Vol II and observations validated by native speakers. The results of this study are vocabularies beginning with o- and go- thirty-two vocabularies all included in the futsuumeishi category 'noun that states a matter or object'. Futsuumeishi 'noun stating a case or object' consists of settogo ya setsubigo no tsuita mono (nouns added to the prefixes $o$ - and go-). Data were analyzed based on the meaning of the dictionary and validated by native (Japanese) with informal interview techniques. The conclusion from the results of this study is that every noun or word containing the prefix o- and go- has a cultural meaning with a group and family concept.
\end{abstract}

Keywords:

Prefixes; bikago; nomina;

cultural significance

Article Info:

First received:

19 November 2019

Available online:

29 May 2020

\section{PENDAHULUAN}

Bahasa adalah lambang bunyi yang bersifat arbitrer, digunakan oleh suatu masyarakat tutur untuk bekerjasama, berkomunikasi, dan mengidentifikasi diri (Chaer, 2000:1). Bahasa itu sistematik yang mempunyai atau diatur oleh sebuah sistem, yaitu aturan dan pola. Pada setiap bahasa aturan ini dapat dilihat dari dua hal, yaitu sistem bunyi dan sistem makna. Jika aturan atau pola ini dilanggar, maka komunikasi dapat terganggu misalnya dapat terjadi kesalahpahaman dalam memahami atau memaknai maksud dari pesan yang ingin disampaikan oleh penutur kepada petutur. Bahasa sebagai alat perekat memiliki fungsi terpenting sebagai alat komunikasi dan interaksi dalam menyatupadankan keluarga, masyarakat, dan bangsa dalam kegiatan sosialisasi (Chaer, 2003:52). Ilmu bahasa yang sering kita sebut dengan linguistik, mempunyai beberapa cabang, salah satunya adalah linguistik antropologi atau antropologi linguistik. Menurut Chaer (2007:6) Linguistik adalah ilmu tentang bahasa atau ilmu yang menjadikan bahasa sebagai objek kajiannnya. Sedangkan menurut Kontjaraningrat (2015:9) antropologi adalah "ilmu tentang manusia" yang mempelajari tentang bentuk fisik maupun sosial dari "ilmu tentang manusia". Istilah linguistik antropologi dan antropologi linguistik sering dipertukarkan pemakaiannya. Meskipun demikian, pengertian kedua istilah ini dapat dibedakan. Jika linguistik antropologi merupakan cabang dari linguistik, sedangkan antropologi linguistik merupakan cabang dari antropologi. Duranti (1997:2-3) mengatakan bahwa perbedaan diantara keduanya tampak pada cara kerja kedua disiplin ilmu ini. Studi linguistik antropologi bermula dari fakta kebahasaan. Data dalam studi linguistik antropologis adalah bahasa yang dapat berupa kosa kata, frase, struktur kalimat, bentukbentuk kalimat, register, perilaku berbahasa, dan sejenisnya.

Berdasarkan data yang berupa bahasa ini, dengan menggunakan metode tertentu, lalu ditafsirkan kedalam aspek antropologi atau budaya yang berada di baliknya. Sebaliknya, antropologi linguistik tidak bermula dari fakta 
kebahasaan, melainkan dari fakta kebudayaan. Contohnya dalam masyarakat Aceh alat yang digunakan untuk membajak sawah disebut langlai. Benda itu (langlai), semula tidak ada nama, namun setelah benda itu tercipta dan menjadi kebiasaan manusia membajak sawah dengan benda itu, barulah kemudian muncul nama atau bahasa untuk menyebutkan benda tersebut; sehingga istilah langlai dalam Bahasa Aceh mengacu pada 'bajak sawah tradisional Aceh (Widyaiswara dan Hodjidjah, 2009:8)

Penelitian ini mengacu pada teori Foley (1997:1) yang mengatakan bahwa Linguistik antropologi memandang bahasa melalui sudut pandang kebudayaan untuk menemukan "makna" dibalik penggunaan bahasa. Pernyataan tersebut didukung oleh Devianty (2017:238) Karena bahasa itu adalah produk budaya dan sekaligus wadah pencapaian kebudayaan dari masyarakat bahasa yang bersangkutan misalnya dalam budaya masyarakat Inggris yang tidak mengenal nasi sebagai makanan pokok, hanya ada kata rice untuk menyatakan nasi, beras, gabah, dan padi. Oleh karena itu, kata rice pada konteks tertentu berarti nasi, pada konteks lain berarti gabah, dan pada konteks lain lagi berarti beras atau padi.

Konsep linguistik antropologi sendiri menurut Foley (1997:3) adalah memandang dan mengkaji bahasa dari sudut pandang antropologi, budaya, dan bahasa untuk menemukan makna di balik pemakaiannya. Foley juga mengatakan bahwa linguistik antropologi adalah disiplin ilmu yang bersifat interpretatif yang lebih jauh mengupas bahasa untuk menemukan pemahaman budaya (cultural understanding).

Salah satu bangsa yang memiliki kebudayaan dalam tindak tutur dalam bahasa adalah Jepang hal ini dapat terlihat dari pemakaian bahasa yang sering ditemui misalnya pada kata 'matsuri' atau 'omatsuri' karena di Jepang sangat kental dengan budaya upacara, peristiwa, peringatan atau perayaan ritual yang dilakukan sejak dulu secara berkelompok untuk mengungkapkan atau menunjukan selamatan, peringatan penting, dan sebagainya maka kata 'matsuri' atau 'omatsuri' ini sangat familiar dalam kehidupan orang Jepang (Sudjianto, 2002:61)

Dapat disimpulkan bahwa, bahasa dalam lingkup budaya sangat terikat dengan latar belakang budaya dalam suatu masyarakat. Karena bahasa sangat dipengaruhi oleh kebudayaan dan cara berpikir manusia atau masyarakat penuturnya, sehingga segala hal yang ada di dalam kebudayaan akan tercermin di dalam sebuah bahasa. Selain itu di dunia ini ada beberapa negara misalnya Jepang, yang memiliki kebudayaan tindak tutur dalam berbahasa, dengan memiliki ciri khas tertentu seperti penghormatan kepada kata-kata tertentu dengan cara memperhalus dan memperindah kata tersebut dengan menambahkan prefiks $O$ dan $G O-$ di depan nomina. Prefiks $o$ - digunakan pada 和語 wago 'kata yang berasal dari bahasa Jepang' sedangkan go- banyak digunakan pada 漢語 kango 'kata yang berasal dari bahasa China'.

Contoh penggunaan prefiks $o$ - di depan nomina sebagai bentuk bikago:

(1) 佐藤 : ミラ.

$$
\begin{aligned}
& \text { Mira } \\
& \text { ミラ: なんですか. } \\
& \text { Nandesuka? } \\
& \text { ‘Ada apa?’ } \\
& \text { 佐藤 : 明日 友達と お花見 をします. } \\
& \text { ミラさんも 一緒に 行きませ } \\
& \text { んか. }
\end{aligned}
$$

Satou : Ashita tomodachi to ohanami o shimasu. Mira san mo isshoni ikimasenka?

'Besok ingin melihat bunga bersama teman. Apakah Mira ingin pergi bersama?'

(MN. SK. I . P. 47)

Tuturan di atas merupakan tuturan antara Satou dan Mira, hubungan antara keduanya adalah pertemanan. Satou menggunakan ragam bikago pada kata 'ohanami' dalam bentuk biasa. Bentuk ini digunakan dalam situasi nonformal. Penanda morfologis bentuk bikago pada nomina yang diberi prefiks $o$ - pada tuturan tersebut digunakan untuk memperindah dan memperhalus kata hanami. Faktor budaya yang melatarbelakangi tuturan tersebut adalah adanya budaya penghormatan terhadap nomina tersebut, dimana ohanami sendiri merupakan suatu bentuk perayaan untuk menikmati keindahan bunga sakura yang 
bermekaran sambil makan-makan, minumminum atau berpesta di bawah pohon sakura (Haryanti, 2013:8).

Berdasakan uraian, penulis tertarik untuk menganalisis makna budaya pada bikago yang mengandung prefiks $o$ - dan go- dalam bahasa Jepang pada buku Minna no Nihonggo 1\&2, Minna no Nihonggo Yasashi Sakubun, Basic Kanji II dan hasil observasi dengan alasan karena ingin mengetahui budaya apa yang terdapat di balik kata-kata yang mengandung prefiks $o$ dan go-.

\section{TINJAUAN PUSTAKA}

\section{(1) Kebudayaan}

Kebudayaan adalah sebuah sistem dari konsep-konsep yang di wariskan dan di ungkapkan dalam bentuk-bentuk simbolik melalui mana manusia berkomunikasi, mengekalkan, dan memperkembangkan pengetahuan tentang kehidupan dan bersikap terhadap kehidupan ini (Geertz dalam Sobur, 2006: 178).

Menurut Koentjaraningrat (2015:146)

Kata "kebudayaan" berasal dari kata Sansekerta buddhayah, yaitu bentuk jamak dari budhi yang berarti "budi" atau "akal". Dengan demikian ke-budaya-an dapat diartikan: " halhal yang bersangkutan dengan akal". Dalam bukunya ia menuliskan konsep "kebudayaan" menurut ilmu antropologi, yaitu keseluruhan sistem gagasan, tindakan, dan hasil karya menusia dalam kehidupan masyarakat yang dijadikan milik diri manusia dengan cara belajar (Koentjaraningrat, 2015:144).

Hal tersebut menyiratkan bahwa hampir seluruh tindakan manusia adalah "kebudayaan" karena hanya sedikit tindakan manusia dalam kehidupan masyarakat yang tidak perlu dibiasakan dengan belajar yaitu tindakan-tindakan yang hanya dilakukan dengan naluri, refleks, atau tindakan akibat proses fisiologi misalnya seperti makan, minum, atau berjalan dengan kedua kakinya.

Berdasarkan definisi tersebut, dapat disimpulkan bahwa "kebudayaan" dan "tindakan kebudayaan" itu adalah segala tindakan yang harus dibiasakan oleh manusia dengan belajar (learned behavior). Koentjaraningrat (2015:165) membagi kebudayaan berdasarkan tujuh unsur, yaitu bahasa, sistem pengetahuan, organisasi sosial, sistem peralatan hidup dan teknologi, sistem mata pencarian hidup, sistem religi, dan kesenian.

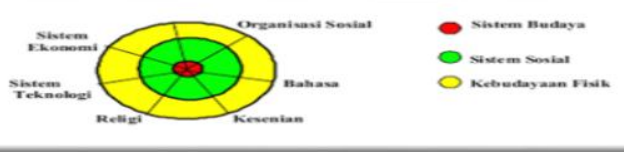

Gambar 2.1 Kerangka Kebudayaan dimana

Sistem Budaya Sebagai Sentralnya

Sumber:http://rahmatmaulana031197.blogspot .com

Dari ketujuh unsur-unsur kebudayaan tersebut penulis hanya memfokuskan untuk meneliti unsur bahasanya saja. Bahasa dan kebudayaan merupakan dua hal yang berbeda, namun mempunyai hubungan yang sangat erat sehingga tidak dapat dipisahkan satu sama lain. Bahasa sangat dipengaruhi oleh kebudayaan sehingga segala hal yang ada dalam kebudayaan akan tercermin di dalam bahasanya. Kebudayaan manusia tidak akan dapat terjadi tanpa bahasa; bahasalah faktor yang memungkinkan terbentuknya kebudayaan.

(2) Hipotesis Sapir Whorf

Menurut Hipotesis Sapir-Whorf (dalam Jatmiko \& Priatmoko 2016:3-4) bahasa menentukan corak suatu masyarakat. Hipotesis itu dikemukakan bahwa bahasa bukan hanya menentukan corak budaya, tetapi juga menentukan cara dan jalan pikiran manusia dan oleh karena itu memepengaruhi pula tindak lakunya. Dengan kata lain, suatu bangsa yang berbeda bahasanya dari bangsa yang lain, akan mempunyai corak budaya dan jalan pikiran yang berbeda pula. Jadi, perbedaanperbedaan budaya dan jalan pikiran manusia itu bersumber dari perbedaan bahasa, atau tanpa adanya bahasa manusia tidak dapat mempunyai jalan pikiran sama sekali. Kalau bahasa itu mempengaruhi kebudayaan dan jalan pikiran manusia, maka ciri-ciri yang ada dalam suatu bahasa akan tercermin pada sikap dan budaya penuturnya.

\section{(3) Linguistik Antropologi}

Berkaitan dengan kajian tentang bahasa dan budaya, terdapat 2 (dua) cabang ilmu yang membahas tentang hal tersebut, yaitu antropologi linguistik dan linguistik 
antropologi. Kedua cabang ilmu tersebut sekilas terlihat mirip. Namun, sebetulnya keduanya merupakan dua hal yang berbeda; baik antropologi linguistik maupun linguistik antropologi sama-sama mengkaji tentang hubungan antara bahasa dan budaya, tetapi memiliki sudut pandang yang berbeda. Salah satu ahli yang mengkaji bidang tersebut adalah Foley. Dia seorang pakar yang berbasis disiplin linguistik, menyebut kajian hubungan antara bahasa dan budaya tersebut dengan istilah "linguistik antropologi".

Menurut Foley (1997:3-5), linguistik antropologi adalah sub-bidang linguistik yang memusatkan perhatian dan menempatkan bahasa dalam konteks sosial dan kebudayaan yang lebih luas, yakni perannya dalam menempa (memperkuat) dan menopang (menjadi tumpuan) praktik kebudayaan dan struktur sosial. Dalam hal ini, bahasa bersumber dari kebiasaan atau kebudayaan masyarakatnya.

Berdasarkan penjelasan tersebut di atas, linguistik antropologi memandang bahasa melalui sudut pandang antropologis, yakni kebudayaan. Oleh karena itu, linguistik antropologi mencari untuk menemukan "makna" di balik penggunaan, salah penggunaan, dan tidak digunakannya bahasa, bentuk bahasa tertentu, register dan style yang berbeda dari bahasa tersebut. Foley beranggapan bahwa pasti ada makna di balik setiap penggunaan atau tidak digunakannya bentuk-bentuk kebahasaan dalam interaksi manusia.

\section{(4) Morfologi}

Salah satu cabang linguistik yang mengkaji tentang struktur atau bentuk kata adalah morfologi. Ramlan (2001: 21) mendefinisikan morfologi sebagai bagian dari ilmu bahasa yang membicarakan atau yang mempelajari selukbeluk bentuk kata serta pengaruh perubahanperubahan bentuk kata itu, baik fungsi gramatik maupun fungsi semantik. Sejalan dengan pendapat Ramlan tersebut, Arifin, Zaenal dan Junaiyah (2007:1-2) mendefinisikan morfologi secara singkat sebagai ilmu bahasa tentang seluk beluk kata atau struktur kata.

Pada bahasa Jepang terdapat proses morfologis yaitu proses pembentukan kata-kata dari satuan lain yang merupakan bentuk dasarnya, yang kemudian mengalami proses pembubuhan afiks, proses pengulangan, dan proses pemajemukan (Ramlan, 2001: 51-52). Ketika penutur menggunakan ragam bikago bahasa Jepang, perubahan yang terjadi hanya berupa pembubuhan afiks berupa prefiks $o$ - dan go-.

\section{(5) Nomina}

Nomina mengacu pada semua hal atau benda yang ada di sekeliling manusia. Menurut Arifin \& Junaiyah (2007:109-110) Nomina (kata benda) dapat dilihat dari segi semantis, sintaksis, dan bentuk. Nomina adalah kata yang mengacu pada manusia, binatang, benda, dan konsep atau pengertian, seperti orang, kursi, kelinci, dan pengetahuan. Selain itu Arifin \& Junaiyah (2007:113-116) juga berpendapat bahwa nomina dapat berupa kata dasar dan kata turunan. Nomina turunan salah satunya dihasilkan lewat afiksasi. Afiksasi adalah proses pembentukan kata lewat penambahan afiks pada kata dasar. Afiks dalam penurunan nomina salah satunya adalah prefiks. Misalnya, prefiks $o$ - dan go- dalam bahasa Jepang. Untuk prefiks o- contohnya pada kata 宅 taku 'rumah' (名詞) +お- $\rightarrow お$ 宅 otaku 'rumah' (名 詞) dan prefiks go- pada kata 両親 ryoushin 'orang tua' (名詞) + ご- $\rightarrow$ ご両親 goryoushin 'orang tua' (名詞) .

Ada beberapa pendapat yang menjelaskan mengenai jenis-jenis meishi.

Situmorang (2007:34) menjelaskan bahwa jenis meishi (名詞 dibagi dalam empat kategori yaitu : futsu meishi (普通名詞), koyuu meishi（固 有名詞）, suushi meishi（数詞名詞）, dan daimeishi（代名詞）

sedangkan menurut Sudjianto (2004:38) meishi dapat dikelompokan menjadi lima jenis yaitu : futsu meishi (普通名詞), koyuu meishi (固 有名詞）, suushi meishi（数詞名詞）, daimeishi （代名詞）dan keshiki meishi（景色名詞）. Dan prefiks o- dan go- masuk dalam kategori Settogo Ya Setsubigo No Tsuita Mono (nomina yang disisipkan prefiks dan/atau sufiks) dalam payung futsuu meishi (普通名詞)

Contoh:

$$
\begin{aligned}
& \text { お金 Okane: uang } \\
& \text { お月さま Otsukisama: bulan }
\end{aligned}
$$

(6) Prefiks $O$ - dan $G o$ -

Prefiks $o$ - dan go- merupakan pembentukan kata dari salah satu afiks dalam bahasa Jepang yang bersifat derivasional. Menurut Koizumi 
(dalam Wiyatasari, 2013:8) afiks derivasional merupakan afiks-afiks yang mengubah kelas kata dan menambah karakteristik gramatikal dari suatu kata yang memiliki kelas/jenis yang sama. Sebagai bahasa aglutinasi yang dalam pembentukan kata pada umumnya ditandai melalui penggabungan stem/akar kata (語幹), yaitu morfem yang menunjukkan makna asli/leksikal dengan afiks yang menunjukkan fungsi gramatikalnya, maka kita akan menjumpai begitu banyak afiksasi dalam bahasa Jepang, dan hampir semua afiksasi termasuk dalam proses derivasi.

Bahasa aglutinasi merupakan bahasa yang dalam pembentukan unsur-unsurnya dilakukan dengan jalan menempelkan atau menambahkan unsur selainnya. Seperti prefiks $o$ - dan go- prefiks ini bisa disebut sebagai "prefiks penghalus", dan bisa melekat pada kata, baik berjenis verba, nomina, maupun adjektiva. Berikut adalah contoh prefiks $o$ - dan go- yang melekat pada nomina dan adjektiva.

Contoh:

a) 宅 taku 'rumah' (名詞) +お- ↔お宅 otaku 'rumah' (名詞)

b) 両親 ryoushin 'orang tua' (名詞) + ご$\rightarrow$ ご両親 goryoushin 'orang tua' (名詞)

c) 忙しい ishogashi 'sibuk' (形容詞) + お$\rightarrow$ お忙しい oishogashi 'sibuk' (形容詞)

d) 多忙 tabou 'sibuk' (形容詞) + ご- $\rightarrow$ ご 多忙 gotabou 'sibuk' (形容詞)

Dari proses derivasi dengan prefiks $o$ - dan go- di atas bisa diketahui bahwa derivatnya atau kata turunannya masih memiliki kelas kata yang sama, namun identitas leksikal antara kata dasar dengan derivatnya adalah berbeda. Hal ini bisa diketahui berdasarkan penguraian fitur semantiknya (Verhaar, 2010 : 391) (dalam Wiyatasari 2013:8).

Nomina宅 'rumah' dan 両親 'orang tua' serta ajektiva 忙しい 'sibuk' dan多忙 'sibuk' memiliki fitur semantik 'ragam biasa', sedangkan nomina お宅 'rumah' dan ご両親 'orang tua' serta ajektiva お忙しい ‘sibuk' dan ご多忙 'sibuk' memiliki fitur semantik 'ragam sopan'.

\section{(7) Bikago}

Bikago merupakan awalan kehormatan yang dapat digunakan dengan kata benda sebagai bagian dari proses pemaknaan subjek dan objek. Tujuan dari penambahan prefiks $o$ - pada bikago bukanlah sebagai penghormatan, tetapi untuk memperindah (Shibatani,1991:374) (dalam Skevik 2009:), dan untuk menunjukkan kualitas dari bahasa yang digunakan oleh pembicara (Wetzel, 2004: 4) dalam Skevik (2009). Penggunaan prefiks $o$ - ini lebih umum digunakan oleh wanita dari pada pria, penggunaan yang berlebihan terkadang menimbulkan masalah, misalnya karena tidak sesuai dengan konteks penggunaannya (Wetzel, 2004:117) (dalam Skevik 2009). Contoh katakata dalam bahasa Jepang yang memiliki awalan o- dan go- yang sering digunakan, misalnya o-sake (minuman beralkohol) dan gohan (nasi).

Menurut Takanao (dalam Sudjianto, 2004:189) menyebutkan bahwa bikago merupakan bagian dari keigo sebagai bahasa yang mengungkapkan rasa hormat terhadap lawan bicara atau orang ketiga. Pada dasarnya keigo

dipakai untuk menghaluskan bahasa yang dipakai pihak pertama untuk menghormati pihak kedua dan ketiga.

\section{(8) Makna Budaya}

Budaya sangat erat dengan kehidupan masyarakat. Setiap budaya yang muncul dalam masyarakat dilambangkan dengan bentukbentuk tertentu yang mengandung makna tertentu pula. Misalnya, dalam masyarakat Aceh alat yang digunakan untuk membajak sawah disebut langlai. Benda itu (langlai), semula tidak ada nama; namun setelah benda itu tercipta dan menjadi kebiasaan manusia membajak sawah dengan benda itu, barulah kemudian muncul nama atau bahasa untuk menyebutkan benda tersebut; sehingga istilah langlai dalam Bahasa Aceh mengacu pada 'bajak sawah tradisional Aceh. Konsep yang ada dalam bahasa Aceh tersebut belum tentu memiliki padanan yang sesuai dengan bahasa kebudayaan lain (Widyaiswara dan Hodjidjah, 2009:8) 


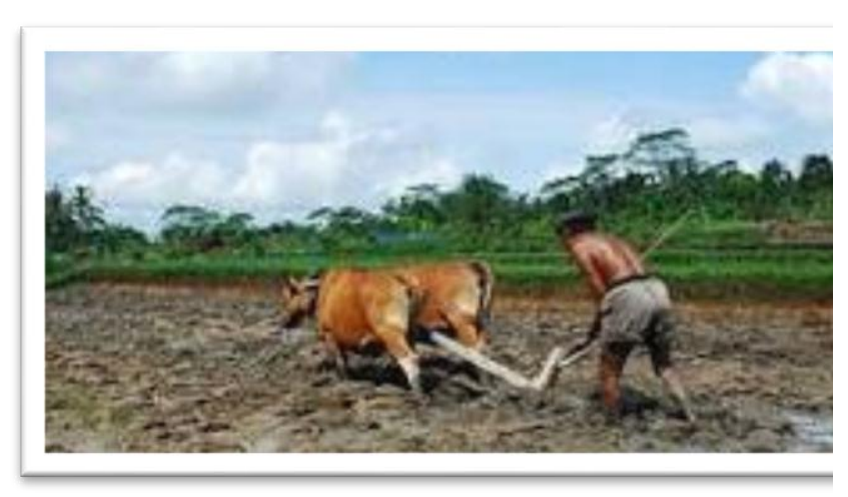

Gambar 2.2 Langlai

Sumber : http://portalcikancah.blogspot.com

Menurut Koentjaraningrat (2015:144) makna budaya adalah konsep yang terkandung di dalam keseluruhan sistem gagasan, tindakan dan hasil karya manusia yang diperoleh dari hasil belajar dalam kehidupan masyarakat yang dijadikan milik manusia itu sendiri. Manusia tidak terlepas dari budaya, keduanya saling memberikan pengaruh. Pengaruh budaya terhadap kepribadian individu akan terlihat pada perilaku yang ditampilkan. Misalnya tercermin dalam cara berbahasa, adat istiadat serta kebiasaanya.

Koentjaraningrat $\quad(2015: 164)$ membagi unsur kebudayaan universal itu menjadi tujuh bagian salah satunya adalah bahasa. pembuktikan bahwa budaya dapat mempengaruhi penggunaan bahasa Bahasa dapat di lihat misalnya, bahasa yang digunakan oleh orang di desa, atau yang dipakai oleh lapisan pegawai (priyayi), atau di dalam istana (keraton), para kepala swapradja di Jawa Tengah, jelas berbeda (Koentjaraningrat, 2015:263) hal tersebut di karenakan budaya stratifikasi sosial yang sangat kental. Misalnya, di daerah Jawa khususnya Surakarta.

Menurut Miyamoto dan Frank (1984:28) konsep makna pada budaya kehidupan masyarakat Jepang di kenal dengan "budaya berkumpul". Yang di maksud dengan berkumpul di sini adalah budaya Jepang yang berpusat dan berpangkal pada kelompok, kelompok yang di maksud adalah keluarga, teman, dan kerabat-kerabat lainnya. Budaya yang berpusat atau berpangkal pada kelompok ini dapat tercerimin misalnya pada kata ohanami 'festival menonton bunga sakura' yang kegiatan utamanya adalah duduk berkumpul bersama dengan teman, kerabat, atau keluarga sambil menikmati makanan atau minuman di bawah pohon sakura yang sedang bermekaran.

Budaya berkumpul ini dimaksudkan untuk saling berinteraksi dan untuk lebih mempererat hubungan kekerabatan serta solidaritas antar sesama, baik dengan sesama keluarga maupun dengan sesama anggota sosial lainnya. Budaya ini sudah menjadi kebiasaan orang Jepang hingga saat ini. Hubungan ini merupakan dasar dari budaya masyarakat Jepang. Bagi orang Jepang, unit kehidupan sosial dalam masyarakat Jepang bukanlah individu, tetapi keluarga sebagai dasar kelompok.

Contoh kata ohanami 'menonton bunga' tersebut di atas merupakan salah satu contoh cerminan bahwa bahasa dapat mencerminkan suatu kebudayaan masyarakat.

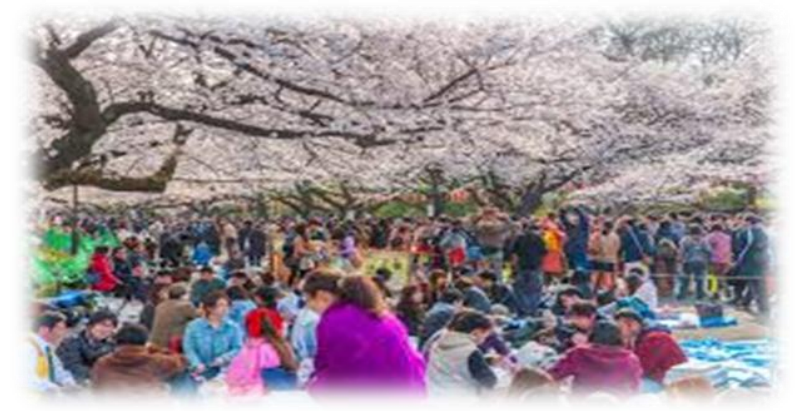

Gambar 2.3 Ohanami

Sumber : https://blog.gaijinpot.com

Masinambouw (2002:22) menyebutkan bahwa bahasa dan kebudayaan merupakan dua sistem yang melekat pada manusia. Kalau kebudayaan itu adalah sistem yang mengatur interaksi manusia di dalam masyarakat, maka kebahasaan adalah suatu sistem yang berfungsi sebagai sarana berlangsungnya interaksi itu. Jadi, budaya itu adalah caranya, sedangkan bahasa adalah sarananya.

Hal tersebut diperkuat dengan ungkapan Geertz (dalam Vita 2012) mengenai makna budaya yaitu suatu sistem simbol yang terdiri dari simbol-simbol dan makna-makna yang dimiliki bersama, yang dapat diindentifikasi, dan bersifat publik; yang dimaksud dengan simbol-simbol tersebut adalah bahasa dan makna-makna yang terkandung di dalam bahasa tersebut, yang kemudian dikenali dan menjadi milik bersama yang sifatnya publik 
atau dapat digunakan secara luas oleh masyarakat penggunanya.

\section{(9) Kerangka Pemikiran}

Penelitian ini bermula pada saat penulis mempunyai ketertarikan terhadap bahasa, kebudayaan dan fenomena budaya dibalik penggunaan bahasa itu sendiri. Hingga terbesit di alam pikiran penulis untuk menuangkan ide ini untuk diteliti dalam skripsi yang akan dibuat oleh penulis. Teori yang memperkuat dasar penelitian ini adalah teori yang dikemukakan oleh seorang ahli linguistik antropologi yaitu William A. Foley. Dalam bukunya itu ia mengungkapkan bahwa linguistik antropologi bertujuan untuk menemukan "makna" dibalik penggunaan bahasa (Foley, 1997:3).

Oleh karena itu, penulis membuat penelitian dengan judul "Makna Budaya Pada Bikago Yang Mengandung Prefiks O- dan GoDalam Bahasa Jepang (Kajian Linguistik Antropologi)". Peneltian ini bertujuan untuk mendeskripsikan makna budaya di balik nomina yang akan disajikan secara deskripsi informal. Dengan data berupa nomina yang mengandung prefiks o-dan go- kemudian mencari arti kata tersebut dalam kamus istilah masyarakat dan kebudayaan Jepang, kemudian mendeskripsikan budaya apa yang terdapat pada nomina tersebut.

\section{METODE PENELITIAN}

\section{Jenis Metode Penelitian}

Pada penelitian ini penulis menggunakan metode deskriptif kualitatif. Metode kualitatif adalah salah satu prosedur penelitian yang menghasilkan data deskriptif berupa ucapan atau tulisan dan perilaku orang-orang yang diamati Bogdan dan Taylor (dalam Moleong, 2015:4).

Pendekatan ini diharapkan mampu menghasilkan suatu uraian mendalam tentang ucapan, tulisan, dan/atau perilaku yang dapat diamati dari suatu individu, kelompok, masyarakat, dan/atau suatu organisasi tertentu dalam suatu setting konteks tertentu yang dikaji dari sudut pandang yang utuh, komprehensif, dan holistik. Jadi dalam hal ini tidak boleh mengisolasikan individu kedalam suatu hipotesis, tetapi perlu memandangnya sebagai bagian dari suatu keutuhan.

\section{Data dan Sumber Data}

Menurut Lofland (dalam Moleong, 2015:157) sumber data utama dalam penelitian kualitatif adalah kata-kata dan tindakan selebihnya adalah data tambahan seperti dokumen dan lain-lain.

Data penelitian kualitatif ini berupa data kebahasaaan dan non kebahasaaan. Data kebahasaaan berupa kosa kata yang mengandung awalan $o$ - dan go- yang berjumlah 32 kosakata, yang terdiri dari 25 kosakata

Berawalan o- dan 7 kosakata berawalan godi dalam buku Minna no Nihonggo (Shokyu 1 dan II) buku Yasashi sakubun dan Basic Kanji II sedangkan data nonkebahasaan berupa makna budaya yang terkandung di dalam kata tersebut. Dari ketiga sumber data tersebut ditemukan sejumlah 32 kosakata, yang menjadi data penelitian ini.

\section{Metode Pengumpulan Data}

Metode yang digunakan untuk mengumpulkan data dalam penelitian ini adalah kepustakaan dan teknik wawancara. Metode kepustakaan diambil dari buku Minna no Nihonggo I dan II. Menurut M.Nazir (2003:27) dalam bukunya yang berjudul Metode Penelitian, ia mengemukakan bahwa studi kepustakaan adalah teknik pengumpulan data dengan mengadakan studi penelaahan terhadap buku-buku, literatur-literatur, catatan-catatan, dan laporan-laporan yang ada hubungannya dengan masalah yang dipecahkan.

Langkah - langkah yang dilakukan dalam mengumpulkan data adalah menginventariskan nomina yang mengandung prefiks $o$ - dan godan mengklasifikasikannya berdasarkan prefiks $o$ - dan go-.

\section{Metode Anlisis Data}

Metode yang digunakan dalam tahap analisis ini adalah metode padan. Metode padan adalah metode analisis data yang alat penentunya berada di luar, terlepas, dan tidak menjadi dari bagian bahasa (langue) yang bersangkutan atau diteliti Sudaryanto (dalam Kesuma, 2007:47).

Upaya yang dilakukan untuk menganalisis data adalah pertama dengan mencari arti kata perkata dalam kamus Jepang-Jepang kokugo jiten, kemudian mendeskripsikan budaya apa yang terdapat pada nomina tersebut. 


\section{Validasi Data}

Untuk mengecek kebenaran data atau informasi yang telah diperoleh maka peneliti melakukan validasi data dengan menanyakan langsung (interview) makna dari nomina tersebut kepada native speaker yang bernama Eisuke (21), Nakano (45), Hirata (21), Baba (32), Kiyoushi (33) dan Moeka (20) .

\section{Kode Data}

Kode data terdiri atas rangkaian huruf dan angka yang terdiri dari beberapa digit. Contoh kode data MN1.010.001 menandakan data diambil dari buku Minna no Nihonggo shokyu 1 halaman 10 dengan nomor urut data 1 .

\section{Teknik Penyajian Hasil Analisis Data}

Data penelitian ini disajikan secara informal. Menurut Sudaryanto (dalam Kesuma 2007:71) penyajian hasil analisis data secara informal adalah penyajian hasil analisis data dengan menggunakan kata-kata biasa. Penyajian secara informal, yaitu rumusan atau kaidah-kaidah yang disampaikan dengan menggunakan kata-kata biasa, kata-kata yang apabila dibaca serta merta dapat dipahami. Penyajian data ini adalah mendeskripsikan makna budaya dibalik nomina yang disajikan secara informal.

\section{HASIL ANALISIS DATA}

Pada bab ini akan di bahas makna budaya yang melatrbelakangi penggunaan prefiks $o$ dan go- pada bikago dalam bahasa Jepang. Dari data yang terkumpul Semuanya termasuk dalam kategori futsuumeishi ' nomina yang menyatakan suatu perkara atau benda'. Futsuumeishi 'nomina yang menyatakan suatu perkara atau benda' terdiri atas settogo ya setsubigo no tsuita mono (nomina yang ditambahkan prefiks $o$ - dan $g o$-).

Dalam bahasa Jepang nomina yang berprefiks o- dan go- disebut bikago. Pada penelitian ini bikago dalam bahasa Jepang akan dianalisis makna budayanya berdasarkan teori makna budaya dari Miyamoto dan Frank tahun (1984). Makna budaya dalam bahasa Jepang menurut Miyamoto mengacu pada konsep kelompok dan keluarga.

Penggunaan prefiks o- dan go- di depan nomina dapat manandakan adanya suatu makna budaya tertentu dibalik kata atau nomina tersebut. Pada pembahasan ini, penulis akan mengkaji penggunaan makna budaya yang terkandung pada nomina yang berprefiks $o$ - dan $g o$-.

Berikut ini hasil analisis pada nomina tersebut:

\section{Makna budaya pada nomina berprefiks o-}

(1)
お弁当
Obentou
'bekal'

(MNII.151.001)

Kata obentou 'bekal' dalam kamus kokugo
jiten online pada alamat website
https://www.weblio.jp/content/弁当 memiliki arti makanan yang dibawa di dalam wadah untuk dimakan di luar. Sementara itu menurut seorang native speaker bernama Eisuke ia berpendapat bahwa obentou 'bekal' adalah makanan yang dibuat dengan cara dikemas di dalam suatu wadah untuk disantap di perjalanan atau tempat tujuan lain seperti kantor, sekolah, objek wisata atau tempat umum lainnya.

Penambahan prefiks $o$ - di depan kata bentou di karenakan kata tersebut berasal dari bahasa Jepang. Makna dari kata obentou 'bekal' yaitu berupa budaya orang Jepang yang gemar hidup sehat dengan membawa bekal makanannya sendiri. Selain itu juga terdapat makna lain yaitu dengan membawa obentou 'bekal' tentu dapat menghemat waktu maupun uang dan juga merupakan tanda cinta ibu kepada anaknya.

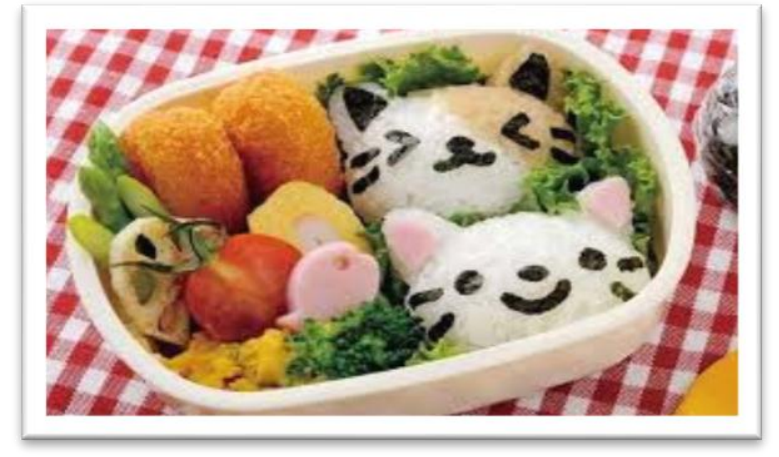

Gambar 1 Obentou 'bekal'

Sumber : http://www.japan-tour.jp

Makna Budaya Pada Nomina Berprefiks Go- 
(2) ご飯

\section{Gohan}

'nasi'

(MN1.042.026)

Dalam kamus kokugo jiten pada alamat website https://www.weblio.jp/content/ご飯 kata gohan 'nasi' memiliki arti bahasa sopan dari kata nasi. Sementara itu, menurut seorang native speaker yang bernama Baba ia berpendapat bahwa arti dari kata gohan 'nasi' adalah istilah sopan yang digunakan untuk kata nasi dan makanan lainnya. Di Jepang, gohan 'nasi' merupakan bahan dasar di hampir seluruh jenis makanan di Jepang, misalnya saja sushi atau lauk lainnya seperti karage atau tempura selalu dihidangkan bersamaan dengan nasi. Oleh karena itu, gohan 'nasi' merupakan bahan makanan pokok yang selalu mereka konsumsi dan sudah dianggap menjadi salah satu bagian dari budaya makanan mereka.
Penambahan prefiks go- di depan kata han di karena kan kata tersebut merupakan kata yang berasal dari bahasa Cina. Makna budaya dari kata gohan 'nasi' adalah masyarakat Jepang yang suka mengkonsumsi nasi. Hal ini dikarenakan mereka menjadikan gohan 'nasi' sebagai bahan makanan pokok yang dapat dikonsumsi setiap hari oleh siapa pun termasuk digunakan sebagai bahan utama pembuatan sushi dengan dengan bahan dasar nasi negara Jepang yang khas dengan dengan tekstur yang khas.

\section{KESIMPULAN}

Berdasarkan hasil analisis dan pembahasan, dapat ditarik kesimpulan bahwa setiap nomina yang mengandung prefiks $o$ - dan go- dalam bahasa Jepang pada buku Minna no Nihonggo 1\&2, Minna no Nihonggo Sakubun, Basic Kanji II dan observasi memiliki konsep makna budaya keluarga dan kelompok.

\section{DAFTAR PUSTAKA}

Arifin, Ferdi, 2015, “ Kajian Linguistik Antropologi: Representasi Simbol Candi Hindu Dalam Kehidupan Manusia" Jurnal Penelitian Humaniora, Vol XIV nomor 22, h. 12-20.

Cangara, Hafied. 2006. Pengantar Ilmu Komunikasi. PT RajaGrafindo Persada. Jakarta.

Camalia, Mahabbatul. 2015. Kajian Antropologi Linguistik: Toponimi Kabupaten Lamongan. Parole. Vol 5 (1)

Chaer, Abdul. 2000. Tata Bahasa Praktis Bahasa Indonesia. Jakarta: Rineka Cipta

Devianty, Rina, 201, "Bahasa Sebagai Cerminan Kebudayaan". Jurnal Tarbiyah,

Vol. 24 nomor 2 , h. 236-237.

Duranti, Alessandro. 1997. Linguistic Anthropology. Cambridge: Cambridge University Press.

Fitria, Vita. 2012. Interpretasi Budaya Clifford Geertz: Agama Sebagai Sistem Budaya. Yogyakarta: UNS Sunan Kalijaga dpk UNY. 
Foley, William A. 1997. Anthropological Linguistics. USA: Blackwell Publishers Inc.

Haryanti,Pitri. 2013. All About Japan. Yogyakarta: Penerbit ANDI Yogyakarta

Hodidjah dan Widyaiswara. 2009. Bahasa Mempengaruhi Budaya atau Sebaliknya. Sumsel: Kemenag Sumsel

International Multicultural (I'Mc) Center Press. 2012. Minna No Nihongo 1. Surabaya.

International Mutual Activity Fondation (IMAF) Press. 2008. Minna No Nihonggo II. Surabaya.

Jatmiko, Juang \& Priatmoko, Agung. 2016. Hubungan Bahasa dan Budaya Berdasarkan Hipotesis Shapir-Whorf . Yogyakarta: Universitas Negeri Yogyakarta

Kano, Chieko, Shimizu Yuri, Takenaka Hiroko dan Ishii Eriko. 1989. Basic Kanji Book II. Tokyo: Bonjinsha Co. Ltd.

Kaoru, Kadowaki \& Kaoru, Nishiuma. 1999. Minna no Nihonggo Yasashi Sakubun. Tokyo: 3A Corporation.

Katubi, 2008, "Linguistik Antropologi: Disiplin Ilmu Yang Termarjinalisasi Pada Program Studi Linguistik" Juarnal Lingua. Vol. 7 nomor 1, h. 11-30.

Kesuma. 2007. Pengantar (Metode) Penelitian Bahasa. Terbitan Pertama. Yogyakarta: Penerbit Carasvatibooks.

Koentjaradiningrat. 2015. Ilmu Pengantar Antropologi. Jakarta: Rineka Cipta

Koizumi, Tamotsu. 1993. Nihongogaku Nyuumon. Tokyo. Taishuukan Shoten

Longdong, Wingston.M.J. 2015. Ungkapan Verbal dan Non Verbal Bermakna

Budaya pada Upacara Adat Maator Mbanua Masyarakat Tonesa (Suatu Kajian Linguistik Antropologi). 3 Februari. Manado: Unsrat

Mahsun. 2007. Metode Penelitian Bahasa, Tahapan, Strategi, Metode, dan Tekniknya. Edisi Revisi Ketiga. Jakarta: PT Raja Grafindo Persada.

Masinambow, E.K.M \& Paul Haenen. 2002. Bahasa Indonesia dan Bahasa Daerah. Jakarta: Yayasan Obor Indonesia

Miyamoto and S. Frank 1984. Social Solidarity Among The Japanese in Seattle. University of Washington Press. United States of America.

M. Nazir. 2003. Metode Penelitian. Jakarta: Ghalia Indonesia.
Moleong, Lexy. 2015. Metodologi Penelitian Kualitatif. Terbitan Ketiga Puluh Empat. Bandung: PT. Remaja Rosdakarya.

Pelawi, 2009, "Aspek Semantik dan Pragmatik Dalam Penerjemahan" Jurnal Lingua Cultura, Vol. III nomor 2, h. 146-151

Ramlan, 2001. Morfologi. Terbitan Kedua Belas. C.V. "Karyono".

Skevik, Karl Andre. (2009). "Language Homogeneity in the Japanese Wikipedia."

Thesis. Oslo University Postgraduate.

Situmorang, Hamzon. 2007. Pengantar Linguistik Bahasa Jepang: Teori dan Fakta. Medan: USU Press.

Sobur, Alex. 2006. Semiotika Komunikasi. Bandung: PT Remaja Rosdakarya

Sudjianto \& Dahidi, Ahmad. 2007. Pengantar Lingustik Bahasa Jepang. Jakarta: Kesaint Blanc.

Kajian Linguistik Antropologis. Disertasi. Yogyakarta:Program Pascasarjana UGM.

Wiyatasari, Reni, 2013, " Pembentukan Kata Secara Derivasonal Dalam Bahasa

Jepang (Suatu Kajian Morfologi)" Jurnal Izumi. Vol II nomor 1, h.6-8.

\section{PUSTAKA LAMAN}

https://www.academia.edu/34554004/Linguis tik_Antropologi diakses pada Jumat, 8 juni 2018 pukul 16:00 WIB

https://www.academia.edu/35660997/BAHA SA_SEBAGAI_CERMIN_KEBUDAYAA $\mathrm{N}$ diakses pada Selasa, 2 Oktober 2018 pukul 01.00 WIB

https://www.weblio.jp/content diakses pada 1 Juli 2019 pukul 01.00 WIB 